\title{
Flow Injection Turbidimetric Determination of Acetylcysteine in Pharmaceutical Formulations Using Silver Nitrate as Precipitant Reagent
}

\author{
Willian T. Suarez, Heberth J. Vieira and Orlando Fatibello-Filho* \\ Departamento de Química, Universidade Federal de São Carlos,CP 676, 13560-970 São Carlos-SP, Brazil
}

\begin{abstract}
Um procedimento de análise por injeção em fluxo turbidimétrico simples, exato e preciso é descrito para determinação de acetilcisteína em formulações farmacêuticas. O procedimento é baseado na precipitação da acetilcisteína com solução de nitrato de prata em meio ácido e o sal insolúvel produzido foi monitorado em $410 \mathrm{~nm}$. A curva analítica para a acetilcisteína foi linear no intervalo de concentração de $1,0 \times 10^{-4}$ a $1,0 \times 10^{-3}$ mol L-1 com um limite de detecção de 5,0 $\times 10^{-5} \mathrm{~mol} \mathrm{~L} \mathrm{~L}^{-1}$. A freqüência de amostragem foi de $60 \mathrm{~h}^{-1}$ e os desvios padrões relativos (RSD)

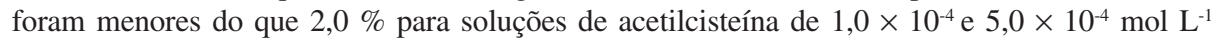
$(n=10)$. A recuperação deste analito em quatro amostras variou de 97,6 a $103 \%$. O test- $t$ pareado mostrou que os resultados obtidos para acetilcisteína em produtos farmacêuticos usando o procedimento em fluxo proposto e o método oficial, foram concordantes em um nível de confiança de $95 \%$.
\end{abstract}

A simple, accurate and precise flow-injection turbidimetric procedure is reported for the determination of acetylcysteine in pharmaceutical formulations. The procedure is based on the precipitation of acetylcysteine with silver nitrate solution in acid medium and the insoluble salt produced was monitored at $410 \mathrm{~nm}$. The analytical curve for acetylcysteine was linear in the concentration range from $1.0 \times 10^{-4}$ to $1.0 \times 10^{-3} \mathrm{~mol} \mathrm{~L}^{-1}$ with a detection limit of $5.0 \times 10^{-5} \mathrm{~mol}$ $\mathrm{L}^{-1}$. The sampling rate was $60 \mathrm{~h}^{-1}$ and the relative standard deviations (RSDs) were less than $2.0 \%$ for $1.0 \times 10^{-4}$ and $5.0 \times 10^{-4} \mathrm{~mol} \mathrm{~L}^{-1}$ acetylcysteine solutions $(\mathrm{n}=10)$. The recovery of this analyte in four samples ranged from 97.6 to $103 \%$. A paired $t$-test showed that all results obtained for acetylcysteine in pharmaceutical products using the proposed flow-injection procedure and the official procedure agreed at the $95 \%$ confidence level.

Keywords: flow injection, turbidimetry, acetylcysteine, pharmaceuticals, silver nitrate

\section{Introduction}

Acetylcysteine (NAC) is used as a mucolytic agent in chronic respiratory illnesses as well an antidote in paracetamol overdoses in the first twelve hours after the ingestion of drug. ${ }^{1}$ More recently, animal and human studies of NAC have shown it to be a powerful antioxidant and a potential therapeutic agent in the treatment of cancer, heart disease, HIV infection, heavy metal toxicity, and other diseases characterized by free radical and oxidant damage. ${ }^{2}$

Among methods used for the determination of acetylcysteine in pharmaceuticals, spectrophotometric procedures $^{3-5}$ are the most often used. These procedures are based on antioxidant characteristic of NAC and uses an oxidant as reagent as iron, ${ }^{6-8}$ bromine, ${ }^{9}$ cerium(IV $)^{10}$ or

*e-mail: bello@dq.ufscar.br reaction of derivatisation with ortho-phthalaldehyde and isoleucine. ${ }^{11,12}$ HPLC, ${ }^{13}$ potentiometry ${ }^{14}$ and voltammetry methods ${ }^{15,16}$ have also been used for the determination of NAC. Chemiluminescence procedure has showed high sensitive in NAC determination. ${ }^{17}$ Some procedures have been described with production of a derivative which can be measured fluorimetrically. ${ }^{18,19}$ The Brazilian Pharmacopoeia ${ }^{20}$ describes a titrimetric procedure for NAC in pharmaceutical formulations, but this procedure is very slow and laborious, and thus less applicable to large-scale analysis. A titrimetric procedure was proposed by Viñas et al. ${ }^{21}$ based on the inhibitory effect of NAC on the silver catalyzed phloxin-persulphate reaction.

Flow injection (FI) analysis is well-established analytical technique that shows advantageous for routine analysis and quality assurance control. Especially in pharmaceutical quality control ${ }^{13,22}$ flow injection systems are appropriate for use in routine analysis in pharma- 
ceutical quality control laboratories due to their simplicity, high sampling rate and the value in reducing reagent consumption when compared with batch procedures. ${ }^{22,23}$

Bergamin-Filho et al. ${ }^{24}$ were the first to employ the injector-commutator and merging zones in which both sample and reagent are introduced into inert carrier streams with synchronized merging. In this configuration, high sampling rate and good accuracy was achieved with low sample and reagent consumption.

In the present work, a simple, accurate and precise flow-injection turbidimetric procedure is reported for the determination of the acetylcysteine in pharmaceutical formulations. The proposed flow injection turbidimetric procedure with symmetric merging zones is based on the reaction between acetylcysteine and $\mathrm{Ag}(\mathrm{I})$ to form a precipitate in suspension that is determined turbidimetrically at $410 \mathrm{~nm}$.

\section{Experimental}

\section{Reagents and solutions}

All reagents were of analytical grade and all solutions were prepared with deionized water from a Millipore (Bedford, MA, USA) Milli-Q system model UV plus ultralow organics water.

A $5.0 \times 10^{-3} \mathrm{~mol} \mathrm{~L}^{-1}$ acetylcysteine stock solution was prepared by dissolving $0.0408 \mathrm{~g}$ of acetylcysteine (Sigma) in $5.0 \times 10^{-2} \mathrm{~mol} \mathrm{~L}^{-1} \mathrm{HNO}_{3}$ solution and the volume was made up to $50 \mathrm{~mL}$ in a calibrated flask using the same solution. Reference solutions containing from $1.0 \times 10^{-4}$ to $1.0 \times 10^{-3} \mathrm{~mol} \mathrm{~L}^{-1}$ of acetylcysteine were prepared by dilution of appropriate volumes of stock solution with $5.0 \times 10^{-2} \mathrm{~mol} \mathrm{~L}^{-1} \mathrm{HNO}_{3}$ solution in a calibrated flask.

A $2.0 \times 10^{-2} \mathrm{~mol} \mathrm{~L}^{-1}$ silver nitrate stock solution was prepared by dissolving $0.3396 \mathrm{~g}$ of this reagent (Aldrich) in $5.0 \times 10^{-2} \mathrm{~mol} \mathrm{~L}^{-1} \mathrm{HNO}_{3}$ solution and the volume was made up to $100 \mathrm{~mL}$ in a calibrated flask using the same acid solution.

\section{Sample preparation}

The determination of acetylcysteine of Brazilian commercial sachets using the proposed flow injection procedure was performed. Ten sachets of each formulation were weighted, powdered and a known accurate amount in the range from 16.32 to $163.2 \mathrm{mg}$ was dissolved with $5.0 \times 10^{-2} \mathrm{~mol} \mathrm{~L}^{-1} \mathrm{HNO}_{3}$ solution, transferred to a $50 \mathrm{~mL}$ calibrated flask and the volume was made up to this volume with the same acid solution. Additional dilutions when necessary were made using $\mathrm{HNO}_{3}$ solution in 50
$\mathrm{mL}$ calibrated flasks. These sample solutions were inserted directly into the flow injection system with the aid of an injector-commutator. The content of acetylcysteine in these samples was determined by interpolation in the calibration curve obtained with several reference solutions in the concentration range from $1.0 \times 10^{-4}$ to $1.0 \times 10^{-3}$ mol L ${ }^{-1}$.

\section{Apparatus}

A Femto (São Paulo, Brazil) model 432 spectrophotometer equipped with a glass flow-cell (optical path of $1.0 \mathrm{~cm}$ ) was used for the turbidity measure at $410 \mathrm{~nm}$ and peak heights were recorded on a Cole Parmer (Chicago, IL, USA) model 1202-0000 two-channel strip-charter recorder. A model 7628-50 twelve-channel Ismatec (Zurich, Switzerland) peristaltic pump supplied with Tygon ${ }^{\circledR}$ pump tubing was used for the propulsion of the solutions. Polyethylene tubing $(0.8 \mathrm{~mm}$ i.d.) was used to assemble the manifold. Sample and reagent solutions were inserted in the flow system with the aid of a laboratory-built threepiece manual injector-commutator made of Perspex ${ }^{\circledR}$, containing two fixed bars and a sliding central bar. ${ }^{25}$

\section{Comparative method}

As a comparative method it was used the potentiometric procedure described in the Brazilian Pharmacopoeia. ${ }^{19}$ In this procedure, the sample solution was potentiometrically titrated with a $0.10 \mathrm{~mol} \mathrm{~L}^{-1}$ mercury nitrate (II) solution, using a gold electrode wire as indicator and saturated calomel reference electrode (SCE) at $25^{\circ} \mathrm{C}$.

\section{Flow diagram}

The flow-injection system with symmetric merging zones procedure proposed in this article is based on the precipitation of acetylcysteine with silver nitrate solution in acid medium ( $\mathrm{pH} \mathrm{1.3)} \mathrm{and} \mathrm{the} \mathrm{insoluble} \mathrm{salt} \mathrm{produced}$ (equation 1) was monitored at $410 \mathrm{~nm}$.

$\mathrm{Ag}_{(\mathrm{aq})}^{+}+\mathrm{RSH}_{(\mathrm{aq})} \stackrel{\mathrm{H}_{2} \mathrm{O}}{\rightleftharpoons} \mathrm{RSAg}_{(\mathrm{aq})}+\mathrm{H}_{3} \mathrm{O}_{(\mathrm{aq})}^{+}$

A schematic diagram of the flow manifold is shown in Figure 1. The injector-commutator (I) is in the sampling position. In this position, the reagent $\left(\mathrm{L}_{1}, 250 \mu \mathrm{L}\right)$ and the sample or reference solution $\left(\mathrm{L}_{2}, 250 \mu \mathrm{L}\right)$ were pumped to fill the reagent and sample loops and the excess of these solutions were propelled back to each vessel (sample vessel (SV) and reagent vessel (RV)). Switching the 


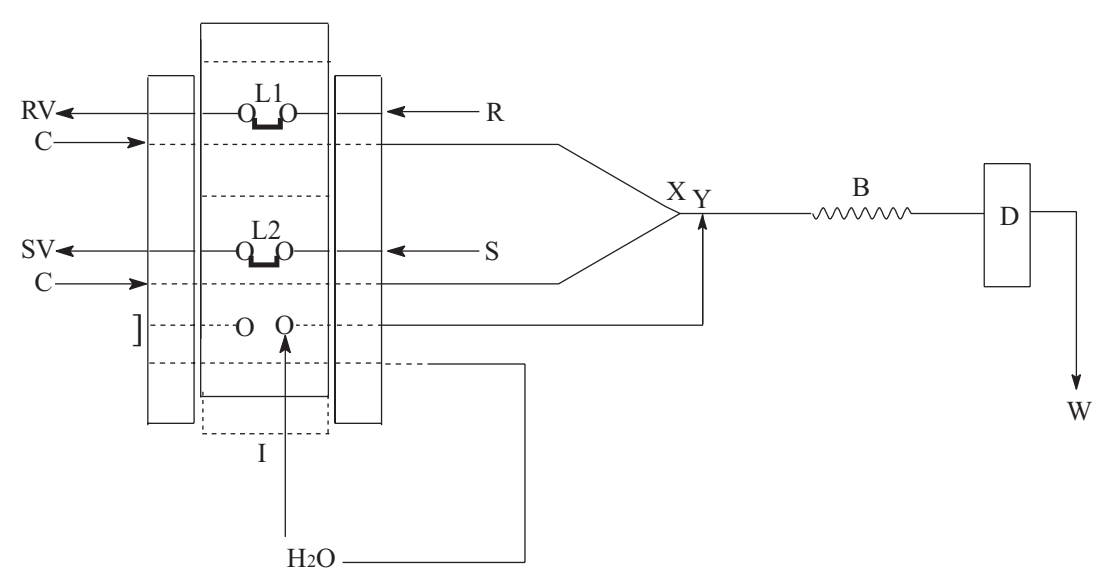

Figure 1. Flow-injection manifold for determination of acetylcysteine. The peristaltic pump is not shown, and the broken lines in the bars of the manual injector (I) show the sample position. C: solution carrier of $\mathrm{HNO}_{3}\left(5.0 \times 10^{-2} \mathrm{~mol} \mathrm{~mL}^{-1} ; 1.7 \mathrm{~mL} \mathrm{~min}^{-1}\right)$; S: sample or reference solution; SV: sample vessel; $\mathrm{R}$ : reagent solution $\left(2.0 \times 10^{-2} \mathrm{~mol} \mathrm{~mL}^{-1} \mathrm{AgNO}_{3}\right)$; RV: reagent vessel; $\mathrm{L}_{1}$ : reagent loop $(250 \mu \mathrm{L}) ; \mathrm{L}_{2}$ : sample loop $(250 \mu \mathrm{L})$; X: confluence point; $\mathrm{Y}$ : entrance of deionized water flowing intermittently at $6.3 \mathrm{~mL} \mathrm{~min}^{-1}$; B: reactor coil $(100 \mathrm{~cm})$; D: detector at $410 \mathrm{~nm}$ and W: waste. The length between the injectorcommutator and confluence $\mathrm{X}$ was $5 \mathrm{~cm}$.

injector-commutator to injection position, the selected volumes of reagent and sample (or reference solution) were injected simultaneously as individual zones into the $5.0 \times 10^{-2} \mathrm{~mol} \mathrm{~L}^{-1} \mathrm{HNO}_{3}$ carrier streams $\left(\mathrm{C} ; 1.7 \mathrm{~mL} \mathrm{~min}^{-1}\right)$ merging at point $\mathrm{X}$. The precipitate formed in the reactor coil B $(100 \mathrm{~cm} \times 0.8 \mathrm{~mm}$ i.d.) was transported to the flowcell (D) and was monitored at $410 \mathrm{~nm}$. When the manual injector was in the sampling position, an intermittent flow of deionized water at a flow rate of $6.3 \mathrm{~mL} \mathrm{~min}^{-1}$ has been pumped into the system by the confluence point $\mathrm{Y}$ to wash the polyethylene tubing and the flow cell.

\section{Results and Discussion}

\section{Reaction conditions and flow-injection parameters}

The merging zones configuration was chosen because very small volumes of reagent (silver nitrate) is consumed in each injection and provides good repeatability and high baseline stability. ${ }^{26}$

In turbidimetry, the transmittance of light through a suspension of precipitate is measured. Thus, initially an UV-Visible absorption spectrum of the precipitate, R-S$\mathrm{Ag}(\mathrm{s})$ formed in the reaction of acetylcysteine and $\mathrm{Ag}(\mathrm{I})$ in acid medium was obtained off-line (not shown). The maximum analytical signal (turbidity) was attained in the wavelength range from 400 to $430 \mathrm{~nm}$. Therefore, a wavelength of $410 \mathrm{~nm}$ was selected for this work.

Several parameters had to be optimized in order to achieve the optimal conditions to promote the reaction between acetylcysteine and $\operatorname{Ag}(\mathrm{I})$ in acid medium. Chemical and flow-injection parameters were optimized by univariate method in order to achieve a compromise between the peak height, sample throughput, reprodu- cibility and stability of baseline. These studies were carried out using a standard solution containing $5.0 \times 10^{-4} \mathrm{~mol} \mathrm{~L}^{-1}$ (81.6 $\mathrm{mg} \mathrm{L}^{-1}$ ) of acetylcysteine.

The effect of the $\mathrm{HNO}_{3}$ concentration used as carrier was investigated in the concentration range from $1.0 \times 10^{-2}$ to $0.4 \mathrm{~mol} \mathrm{~L}^{-1}$. The analytical signal increased with the $\mathrm{HNO}_{3}$ concentration up to $5.0 \times 10^{-2} \mathrm{~mol} \mathrm{~L}^{-1}$ above which it remained constant. A $5.0 \times 10^{-2} \mathrm{~mol} \mathrm{~L}^{-1} \mathrm{HNO}_{3}$ solution was selected in all further experiments.

The influence of the silver nitrate concentration on the analytical signal in the concentration range from $5.0 \times 10^{-4}$ to $5.0 \times 10^{-2} \mathrm{~mol} \mathrm{~L}^{-1}$ for $5.0 \times 10^{-4} \mathrm{~mol} \mathrm{~L}^{-1}$ acetylcysteine reference solution was shown in Figure 2. It was observed that the peaks height increased with the silver nitrate concentration up to $1.0 \times 10^{-2} \mathrm{~mol} \mathrm{~mL}^{-1}$, maintained practically constant up to $5.0 \times 10^{-2} \mathrm{~mol} \mathrm{~L}^{-1}$ concentration. Therefore, a $2.0 \times 10^{-2} \mathrm{~mol} \mathrm{~mL}^{-1}$ silver nitrate solution was chosen for further experiments to avoid rapid dilution of this reagent after each measurement cycle.

The effect of the sample and reagent volumes injected was studied by varying the volumes of $\mathrm{L}_{1}$ and $\mathrm{L}_{2}$ loops between $100-500 \mu \mathrm{L}$. The turbidity increased with greater volumes up to $250 \mu \mathrm{L}$ for sample and up to $250 \mu \mathrm{L}$ for reagent, above which the turbidity remained practically constant. Sample and reagent volumes of $250 \mu \mathrm{L}$ and $250 \mu \mathrm{L}$ were chosen as a good compromise between analytical signal and sampling rate.

The flow rate was optimized in the range from 0.5 to $6.3 \mathrm{~mL} \mathrm{~min}^{-1}$, in each channel. It was found that the best analytical signal was reached using a carrier flow of 1.7

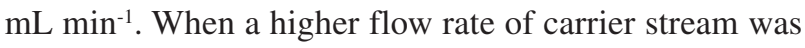
employed, the turbidity signal decreased probably due to a shorter residence time. Thus, a $1.7 \mathrm{~mL} \mathrm{m^{-1 }}$ flow 


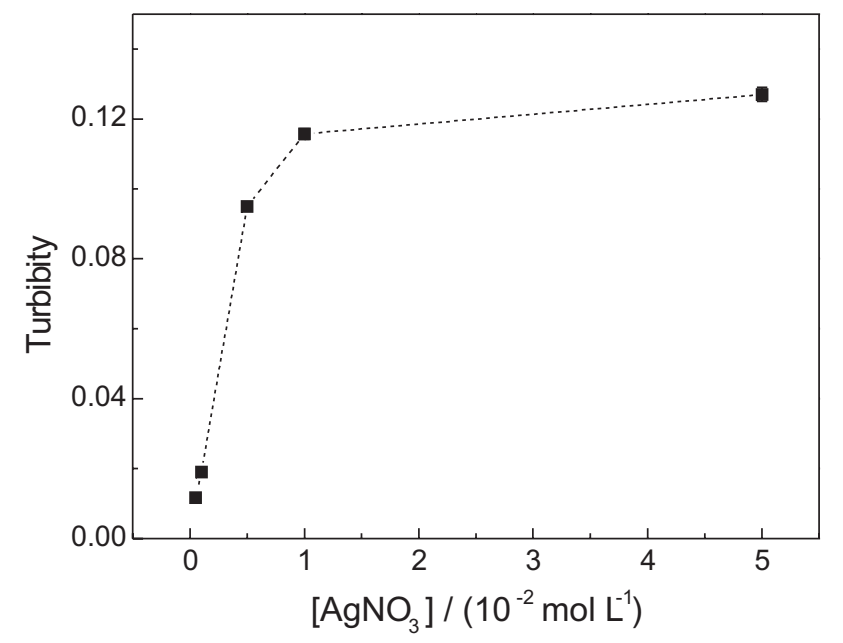

Figure 2. Effect of silver nitrate concentration on acetylcysteine determination.

rate in each channel was established to further experiments.

The effect of the reactor coil length (B) was investigated in the range from 25 to $150 \mathrm{~cm}$ at constant flow rate. In this study, acetylcysteine reference solution in the concentration $5.0 \times 10^{-4} \mathrm{~mol} \mathrm{~L}^{-1}$ was used. The peak heights increased with the increases of the reaction coil up to $100 \mathrm{~cm}$, above which a slight decrease was observed probably due to the dispersion of the sample zone. A 100 $\mathrm{cm}$ reaction coil was chosen in all further experiments

\section{Effect of colloid protectors}

Colloid protectors have been used in previous flow injection turbidimetric procedure ${ }^{27}$ as stabilizers of suspensions and to avoid adherence of the precipitate in the inner walls of the tubes and/or coils. The effect of colloid protectors poly(ethyleneglycol), poly (vinylalcohol), Triton (X-100) and agar-agar on the sensitivity and washing-time was studied in three different concentrations $(0.010,0.025$ and $0.050 \%, \mathrm{~m} / \mathrm{v})$ of each compound added to all solutions $\left(\mathrm{HNO}_{3}\right.$ carrier, sample and reagent). A slight increase ( $c a .3 \%$ ) of analytical signal was obtained with poly(vinylalcohol) solution. On the other hand, the analytical signal do not changed with the use of other colloid protectors. As the increase of the analytical signal was very small by using poly (vinylalcohol) solution, to avoid adherence of precipitate in the inner walls of the tubes, coil and/or cell, an intermittent flow of deionized water at a flow rate of 6.3 $\mathrm{mL} \min ^{-1}$ has been pumped into the system by the confluence point $\mathrm{Y}$ to wash the polyethylene tubing and the flow cell (see Figure 1). Before the insertion of sample solution and the analytical signal have been recorded, the injector is commuted to sampling position. Then, a flow of washing solution merge in the confluence point $\mathrm{Y}$ providing a flow-rate much higher than the carrier stream whereby the baseline is attained much more quickly, avoiding the impregnation of colloidal particles in the flow cell.

\section{Selectivity and recovery studies}

The selectivity of proposed flow injection procedure was evaluated studying the potential interference of excipients, which are commonly used in pharmaceutical preparations such as saccharine, sucrose, sodium dihydrogenphosphate, EDTA, $\mathrm{NaHSO}_{3}$, benzalkonium chloride and sodium benzoate. In this study, three solutions of known concentrations $\left(1.0 \times 10^{-5}, 1.0 \times 10^{-4}\right.$ and $1.0 \times$ $10^{-3} \mathrm{~mol} \mathrm{~L}^{-1}$ ) of these substances containing $1.0 \times 10^{-4} \mathrm{~mol}$ $\mathrm{mL}^{-1}$ acetylcysteine reference solution were injected in the flow system and the analytical signal obtained was compared with the solution containing only acetylcysteine at same concentration. No interferences were observed by saccharine, sucrose, phosphate and EDTA at same concentration of acetylcysteine but some interference ( $c a$. 8-12\%) was observed in higher concentrations. Saccharin and benzoate react with $\mathrm{Ag}(\mathrm{I})$ to produce silver insoluble salts. However, in the studied conditions of the proposed method $(\mathrm{pH}=1.3)$ significant fractions of saccharinate $\left(\mathrm{pK}_{\mathrm{a}}=1.6\right)$ and benzoate $\left(\mathrm{pK}_{\mathrm{a}}=4.2\right)$ are present in the corresponding protonated form, thus as expect those excipient do not cause any interference. A strongly interference was observed by benzalkonium chloride in all concentrations tested, since the chloride ion react strongly with $\operatorname{Ag}(\mathrm{I})$. Nasal liquid products can not be analyzed with the proposed method, due to the high concentration ( $c a .0 .28 \mathrm{mg} \mathrm{mL}^{-1}$ ) of benzalkonium chloride.

The recovery results obtained varied between 97.6 to $103 \%$, show no significant matrix effect of the sample. The analyses of commercial samples were performed using a calibration curve.

\section{Calibration graph and applications}

The proposed flow injection system under the optimized conditions was applied to determine acetylcysteine in commercial formulations. The results of the analysis of acetylcysteine in commercial formulations are presented in Table 1. As it can be seen, good agreement between the result obtained in the determination of acetylcysteine by the proposed flow injection procedure and the titrimetric method described in the Brazilian 
Table 1. Determination of acetylcysteine in commercial formulations by using flow-injection turbidimetric and Official Method ${ }^{20}$

\begin{tabular}{lccccc}
\hline Samples & \multicolumn{3}{c}{ Acetylcysteine / $\left(\mathrm{mg} \mathrm{g}^{-1}\right)$} & \multicolumn{2}{c}{ Relative error / \% } \\
\cline { 2 - 6 } & Labelled & Official Method & Flow Procedure & $\mathrm{Er}_{1}$ & $\mathrm{Er}_{2}$ \\
\hline A & 40 & $39 \pm 1$ & $39.2 \pm 0.3$ & -2.0 & 0.5 \\
B & 40 & $39 \pm 1$ & $38.2 \pm 0.1$ & -4.5 & -2.0 \\
C & 20 & $19.7 \pm 0.2$ & $19.7 \pm 0.2$ & -1.5 & 0 \\
D & 20 & $20.1 \pm 0.1$ & $20.2 \pm 0.2$ & 0.5 & 0.5 \\
\hline
\end{tabular}

$\mathrm{n}=3$, mean \pm standard deviation, $95 \%$ confidence level. $\mathrm{Er}_{1}=$ relative error flow procedure $v s$. labelled value and $\mathrm{Er}_{2}=$ relative error flow procedure versus official method. The analyzed samples contained some inactive ingredients: food yellow 3 , sucrose, orange flavoring, sodium bicarbonate, anhydrous citric acid, aspartame, flavoring, sodium saccharin, fructose, orange essence, talc and colloidal silicon dioxide.

Table 2. Analytical features of flow procedures for acetylcysteine determination

\begin{tabular}{|c|c|c|c|c|c|c|}
\hline Analytical features & Sanchez-Pedeño et al..$^{5}$ & Fornazari et al. $^{7}$ & Hernandez et al. ${ }^{12}$ & Suarez et al. ${ }^{9}$ & $\begin{array}{c}\text { Vieira and } \\
\text { Fatibello-Filho }{ }^{10}\end{array}$ & $\begin{array}{l}\text { Proposed } \\
\text { system }\end{array}$ \\
\hline Linear range / $\left(\mu \mathrm{mol} \mathrm{L}^{-1}\right)$ & 50 to 5000 & 3.5 to 430 & 98 to 980 & 160 to 1600 & 6.5 to 130 & 100 to 1000 \\
\hline Detection limit / $\left(\mu \mathrm{mol} \mathrm{L}^{-1}\right)$ & 10 & 0.63 & 45 & 80 & 5.0 & 50 \\
\hline Sampling rate / $\left(\operatorname{det} h^{-1}\right)$ & 45 & 60 & 126 & 60 & 60 & 60 \\
\hline $\mathrm{RSD} / \%\left(\mu \mathrm{mol} \mathrm{L}^{-1}\right)$ & $3.4(500)$ & $1.4(250)$ & $0.6(620)$ & $1.2(530)$ & $1.4(22)$ & $<2.0(500)$ \\
\hline
\end{tabular}

Pharmacopoeia ${ }^{20}$ were found ( $t$-test). In addition, it also agreed with those declared on the labels confirming the accuracy of the flow injection turbidimetric method. The calibration curve for acetylcysteine was linear in the concentration range from $1.0 \times 10^{-4}$ to $1.0 \times 10^{-3} \mathrm{~mol} \mathrm{~L}^{-1}$ $(\mathrm{T}=-0.025+480.10 \times[\mathrm{NAC}] ; \mathrm{r}=0.9993$, where $\mathrm{T}$ is the Turbidity ( $\mathrm{T}=-\log$ Transmittance) and $[\mathrm{NAC}]$ is acetylcysteine concentration in $\mathrm{mol} \mathrm{L}^{-1}$.

The detection limit of $5 \times 10^{-5} \mathrm{~mol} \mathrm{~L}^{-1}$ (three times blank standard deviation/slope of analytical curve) and sampling rate of 60 determinations per hour were obtained. As can be seen in the Table 2, analytical features compare favorably with those flow injection procedures described in the literature. Linear range was also comparable to the described flow procedures in the Table 2 . The spectrophotometric flow procedure described by SanchezPedreño et al..$^{5}$ have large linear range when compared with proposed procedure, but that employs an expensive reagent, palladium dichloride as standard solution.

\section{Conclusions}

The proposed flow-injection merging zones procedure developed in this work allows the determination of acetylcysteine in two pharmaceuticals products with consumption of $0.84 \mathrm{mg}$ of silver nitrate as precipitant reagent by determination. The intermittent flow of deionized water allowed the on line cleaning of the system. The proposed method is accurate, precise and cheap when compared with enzymatic procedures, ${ }^{3,4}$ spectrophotometric procedures ${ }^{6,8,11}$ and other flow spectrophotometric procedures with comparable analytical frequency, ${ }^{7,9,10}$ as can be seen in the Table 2 . The proposed flow procedure have smaller limit of detection when compared with spectrophotometric procedure. ${ }^{9}$

\section{Acknowledgments}

The scholarship granted to W.T.S and H.J.V. from CNPq and CAPES respectively, are gratefully acknowledged.

\section{References}

1. Degroote, J.; Vansteenbergen, W.; Acta Gastro-ent. Belg. 1995, $58,326$.

2. Holdiness, M. R.; Clin. Pharmacokinet. 1991, 20, 123.

3. Garcia-Molina, F.; Penalver, M. J.; Rodriguez-Lopez, J. N.; Garcia-Canovas, F.; Tudela, J.; J. Agric. Food Chem. 2005, 53, 6183.

4. Ogwu, V.; Cohen, G.; Free Radical Biol. Med. 1998, 25, 362.

5. Sanchez-Pedreño, C.; Albero, M. I.; Garcia, M. S.; Rodenas, V.; Analyst 1992, 117, 925.

6. Abu Eid, M.; Mikrochim. Acta 1998, 129, 91.

7. Fornazari, A.; Suarez, W. T.; Vieira, H. J.; Fatibello-Filho, O.; Acta. Chim. Slov. 2005, 52, 164.

8. Raggi, M. A.; Cavrini, V.; Dipietra, A. M.; J. Pharm. Sci. 1982, $71,1384$.

9. Suarez, W. T.; Vieira, H. J.; Fatibello-Filho, O.; J. Pharm. Biomed. Anal. 2005, 37, 771.

10. Vieira, H. J.; Fatibello-Filho, O.; Quim. Nova 2005, 28, 797.

11. Alvarez-Coque, M. C. G.; Hernandez, M. J. M.; Camanas, R. M. V.; Fernandez, C. M.; Analyst 1989, 114, 975.

12. Hernandez, M. J. M.; Alvarez Coque, M. C. G.; Domingo, E. B.; Camanas, R. M. V.; Pharmazie 1990, 45, 745. 
13. USP, United States Pharmacopeial XXII; U.S Pharmacopeial Convention: Rockville, MD, 1990.

14. Kolar, M.; Dobcnik, D.; Pharmazie 2003, 58, 25.

15. do Carmo, D. R.; da Silva, R. M.; Stradiotto, N. R.; J. Braz. Chem. Soc. 2003, 14, 616.

16. Suarez, W. T.; Marcolino, L. H.; Fatibello-Filho, O.; Microchem. J. 2006, 82, 163.

17. Du, H. X.; Li, Y. H.; Lu, J. R.; Anal. Chim. Acta 2001, 448, 79.

18. Vannecke, C.; Van Gyseghem, E.; Bloomfield, M. S.; Coomber, T.; Vander Heyden, Y.; Massart, D. L.; Anal. Chim. Acta 2001, 446, 413.

19. Al-Ghannam, S. M.; El-Brashy, A. M.; Al-Farhan, B. S.; Farmaco 2002, 57, 625.

20. Farmacopéia Brasileira; Organização Andrei Editora: São Paulo, 1977.

21. Vinãs, P.; Córdoba, M. H.; Sánchez-Pedreño, C.; Analyst 1990 , $115,757$.
22. Martínez-Calatayud, J.; Flow Injection Analysis of Pharmaceuticals - Automation in Laboratory, $1^{\text {st }}$ ed.; Taylor \& Francis Inc., 1996.

23. Rocha, F. R. P.; Nóbrega, J. A.; Fatibello-Filho, O.; Green Chem. 2001, 3, 216.

24. Bergamin-Filho, H.; Zagatto, E. A. G.; Krug, F. J.; Reis, B. F.; Anal. Chim. Acta 1978, 101, 17.

25. Reis, B. F.; Bergamin-Filho, H.; Quim. Nova 1993, 16, 570.

26. Reis, B. F.; Giné, M. F.; Kronka, E. A. M.; Quim. Nova 1989 , 12,82 .

27. Ruzicka, J.; Hansen, E. H.; Flow Injection Analysis, John Wiley \& Sons: New York, 1988.

Received: November 1, 2006

Web Release Date: August 20, 2007

FAPESP helped in meeting the publication costs of this article. 